\title{
Review
}

\section{Dynamics of land use, degradation and sustainability of the Nigerian agricultural systems}

\author{
Abayomi Samuel Oyekale \\ Department of Agricultural Economics and Extension, North-West University Mafikeng Campus, \\ Mmabatho 2735 South Africa. E-mail: abayomi.oyekale@nwu.ac.za
}

Accepted 9 November 2012

\begin{abstract}
Land degradation and persistent decline in agricultural productivity in Nigeria are issues of concern to government since the food production system is adversely affected. This has affected the carrying capacity of available natural resources with many of the rapidly increasing population not able to meet their basic food needs. Policy makers have now realized that for any sustainability of economic growth and development, appropriate policy to reverse the trend of land degradation is a necessity that cannot be compromised. This review shows that the trends of land use have shown relatively high degree of dependence on forestland for agricultural expansion and other industrial/urban uses. It is therefore important for the government to ensure adequate land use planning in conjunction with all stakeholders in the agricultural sector. Such plans should critically evaluate nation's needs of land in the nearest future and how current uses can ensure sustainability in the long term period.
\end{abstract}

Key words: Land use, degradation, sustainability, carrying capacity, Nigeria

\section{INTRODUCTION}

The importance of agriculture in Nigerian economy cannot be over-emphasized. Specifically, agriculture contributes more than $40 \%$ of the total annual GDP, employs about $68 \%$ of the labour force, accounts for over $70 \%$ of the non-oil exports, and provides over $80 \%$ of the food needs of the country. However, the small-scale farmers that dominate the sector are facing serious problems in getting good land due to progressive growth in population, land degradation, and inadequate planning in the use of available land. In spite of massive government investment in the sector and related programmes over the years, in the form of input subsidies, the River Basin Development Authorities, Agricultural Development Projects (ADPs), Green Revolution, Operation Feed the Nation, Directorate for Food, Roads and Rural Infrastructure (DFRRI), among others, the sector's performance is still far below expectation (National Bureau of Statistics, 2011).

The Nigerian small-scale farmers largely depend on traditional methods of farming. These farmers are facing various land use constraints, which is one of the major sources of declines in agricultural productivity. Even if rural households choose to stay on degraded land, its declining productivity will be unable to support growing rural populations, not to consider the nation as a whole. Thus, some households are forced to abandon existing agricultural areas in search of new forest land. Where land is scarce, continuous cropping on fragmented pieces of degraded farm plots persists with little or no soil conservation investments, and resource productivity eventually decreases (FAO, 1991; Walker, 2002).

Agriculture in Nigeria involves four broad systems of land use, which are crop production, animal husbandry, fishery and forestry. Crop production involves three types of farming which could be rotational fallow, semipermanent or permanent cultivation and mixed farming. Permanent cultivation may be rain-fed system or irrigated. Rotational fallow type is only common in sparsely populated areas. Moreover, in Nigeria, much attention is focused on urban land use relative to that of the rural area. In essence, while the government regulates land use in urban areas, the rural areas are 
characterized by free holding through the predominant land tenure systems. The alarming rate at which prime and productive agricultural lands at the fringes of urban centers are being lost to physical development may have a very significant implication for the future food security in the country. Increased investment in agricultural lands and agricultural inputs is still a subject that requires better consideration to forestall future shortage in food security (Akinbola, 1993; FAO, 2000; Oyekale, 2007).

Low resource productivity of Nigerian agriculture is a reflection of its comparatively low input use (FAO, 2000). Reardon (1998) noted that low use of fertilizer across African countries is a major cause of concern, both from the food production and environmental perspectives. FAO (1998) submitted that shortage of good quality agricultural land for smallholder is a problem in many regions of the world. Payment of compensation in cash or in kind for the use of land no doubt affects land use intensity (Adegboye, 1986). According to Nwosu (1991), the government of Nigeria has been acquiring large tracts of land for agricultural and non-agricultural purposes. Therefore, access to land through ownership or secure tenure is a sine qua non for improving agricultural productivity. Without secure land use rights, farmers have little or no access to credit or the benefits of membership in rural organizations. Moreover, with no stake in the land or assurance of access to it, farmers have few incentives to engage in sustainable agricultural practices or to consider the long-term environmental impact of over-exploitation of the land's nutrients (Saka et al., 2011).

There are various factors that can influence or affect the use of land. These factors include natural disasters, which may include flooding (which leads to erosion of soil), wind erosion, earthquakes, volcanic eruption, fire etc. Land for agricultural production is basically affected by the land tenure system. The land for agricultural production and the tenure system go hand in hand. This is predominant in the rural areas.

In the rural areas, land use patterns are governed mainly by the requirements of the agricultural industry, which is important for the livelihood of the people. The use of land for village construction, local markets construction, road construction, church and mosque buildings are of secondary importance. Although, agriculture remains the dominant consideration in the land use decision of farm households, the same forces such as increasing population, the requirement of new crops, the growth of commerce and government action with regards to the preservation of the country's forest wealth have somehow altered traditional concept of land use (Adegboye, 1966; 1986; Oyekale, 2007).

In Nigeria, persistent stagnation in agricultural production is now a matter of serious concern. Although outputs in some crops have recently increased, it had been realized that most of these increases resulted from increase in land areas cultivated (Falusi, 1997). Thus, increasing crop production puts more pressure on the forest, and it is not sure whether this can be sustained as population increases. Furthermore, population growth on degrading land is a major constraint to availability of fertile arable land for agricultural production in Nigeria. Table 1 reveals that although 0.6314 hectare of land supported one person in 2006, only 0.4467 hectare would be supporting one person in 2020. The gravity of the problem will be well conceptualized if one realizes that over the years, restoration of Nigerian land fertility through shifting cultivation is a mere dream. In the absence of sporadic development in agricultural research and technological advancements, it is not surprising that the food problem remain insurmountable more than five decades after national independence (Oyekale, 2007; Saka et al., 2011).

Moreover, in Nigeria, small-scale farmers produce about $90 \%$ of the agricultural outputs. Because of generally low use of chemical fertilizers to make up for soil nutrient depletion, and non-availability of high yielding crop varieties with strong resistance to environmental stress and declining soil fertility, among other constraints, crop yields are very low, even when compared with some countries in West Africa. For instance, FAO noted that in 2000, rice yields in Cameroon, Ghana and Nigeria were $3400,1613.5$ and $1499.8 \mathrm{~kg} / \mathrm{ha}$, respectively. Thus, Nigerian peasant farmers will have to rely so much on increasing crop output by agricultural land expansion. Without a long term planning and sound perspective into the future use of forests, Nigeria may soon have her forestlands completely exhausted, with serious grave consequences for the survival of future generations (FAO, 1991; Oyekale, 2007). Therefore, increasing rates of tropical deforestation have called attention to the problem of optimal allocation of forestland in developing countries. There are important reasons underlying this concern. First is the fact that empirical evidence indicates that the proximate cause of tropical degradation is the conversion of forestland to alternative uses, principally agriculture. In addition, there is growing evidence that current patterns and rates of forest conversion and degradation in tropical countries may not be "optimal" but excessive, resulting from widespread market and policy failures that foster further deforestation (Barbier and Burgess, 1997). In other words, conversion of tropical forests to alternative uses, such as agriculture, may not always be the most economically efficient land use option. Consequently, the concern that deforestation may hinder opportunities for sustainable agricultural production has led to increasing interest in rationalizing the decision-making process with respect to the allocation and use of tropical forestlands (Allen and Barnes, 1985).

These growing concerns notwithstanding, pressure to exploit and clear natural forest have not stopped (World Bank, 1992). The rate of deforestation in Nigeria was $2.6 \%$ in 2000 (World Bank, 2001). Since a large proportion 
Table 1. Declining trend in Nigeria's per capita hectares in selected years.

\begin{tabular}{ccc}
\hline Year & Number of ha per person & Number of persons $/ \mathbf{K m}^{2}$ \\
\hline 2006 & 0.6354 & 1577.06 \\
2007 & 0.6198 & 1616.80 \\
2008 & 0.6045 & 1657.67 \\
2009 & 0.5895 & 1699.73 \\
2010 & 0.5749 & 1743.02 \\
2011 & 0.5606 & 1787.56 \\
2012 & 0.5466 & 1833.30 \\
2013 & 0.5329 & 1880.31 \\
2014 & 0.5196 & 1928.57 \\
2015 & 0.5066 & 1978.12 \\
2016 & 0.4939 & 2028.95 \\
2017 & 0.4815 & 2081.02 \\
2019 & 0.4695 & 2134.18 \\
2020 & 0.4579 & 2188.24 \\
\hline
\end{tabular}

Source: Based on population projections by FAOSTAT (2012).

of the population directly depends on resources from the forests, deficient planning in the use of remaining land will have many social, economic and ecological effects on the Nigerian economy. Specifically, deforestation will result into many negative conseq-uences. The loss of forest and woodlands is perfectly connected to desertification. Fewer trees translate into an insecure future for forest workers. Heavy rainfall and high sunlight quickly damage the topsoil in cleared tropical forests as the intensity of erosion and soil degradation increases. In such circumstances, the forest will take much longer time to regenerate and the land will not be suitable for agricultural use for quite some time, talk less of sustaining yields (Hui, 1997).

In order to therefore address natural resource degradation and food insecurity, the logical and paramount goal that faces Nigerian food policy makers is the development of progress pathways that enhance sustainable natural resource management and increased food production. This is the only way to harmonize population growth with people's increasing food demand so that the nation can steadily achieve its medium term development goal.

\section{LAND USE CHANGES IN NIGERIA}

Land is the pivot of man's absolute existence. Sheng (1989) stressed this by asserting that through the past, in the present, and through the foreseeable future, soil continues to be the foundation of our food supply chain, which is a vital recurrent and capital resource of any nation. However, Vink (1975) observed that in most cases, because of the temporary high economic gains, man may not care about the effect of the use to which land is subjected to. The need for putting land to optimum use through adequate and effective planning has never been greatly felt than at present, when rapid population growth and urban expansion are making available agricultural land scarce (Akinbola, 1993).

According to Adegeye and Dittoh (1985), land is obviously the most important natural resource for agricultural production and it is often given a wide economic definition to include all materials and forces that are supplied by nature for use in the production of goods and services. In other words, land in economic sense includes all other natural resources such as water, forests, soil, climate etc., as well as mineral resources. No significant agricultural production can take place without the land, and in many cases, quite large tracts of large areas of land are needed for the cultivation of crops and rearing of animals.

In Nigeria, as well as in most African countries, the importance of land is far beyond its use as a factor of production. Land could in some cases even be synonymous with clan, family, tribe, custom or religion. Land, therefore, has economic, religious, cultural and tribal importance in most African countries.

Land use in Nigeria will be broadly classified into forest, agricultural land and other land. Data on forest include woodland, and it took cognizance of natural and planted forests. The agricultural land classification considers the land under arable land, permanent crops and permanent pasture, while other land focuses on such nonagricultural uses of land for such purposes as road construction, industrialization, housing etc. Table 2 shows that average agricultural land area increased from $69,004,000$ ha in 1961 to 1965 to $72,580,200$ ha in 1991 
Table 2. Average area of land used for agriculture and forestry in Nigeria ('000ha) (1961-2009)

\begin{tabular}{|c|c|c|c|c|c|c|c|c|}
\hline \multirow{2}{*}{ Years } & \multicolumn{2}{|c|}{ Agricultural area } & \multicolumn{2}{|c|}{ Arable land } & \multicolumn{2}{|c|}{ Permanent crops } & \multicolumn{2}{|c|}{ Forestland } \\
\hline & Mean & Std. dev. & Mean & Std. dev. & Mean & Std. dev. & Mean & Std. dev \\
\hline 1961-1965 & 69004.00 & 162.88 & 26600.00 & 158.11 & 2404.00 & 5.48 & - & - \\
\hline 1966-1970 & 69524.00 & 281.74 & 27084.00 & 257.33 & 2440.00 & 25.25 & - & - \\
\hline 1971-1975 & 69920.00 & 44.72 & 27436.00 & 35.78 & 2484.00 & 8.94 & - & - \\
\hline $1976-1980$ & 70259.00 & 104.79 & 27736.00 & 95.29 & 2523.00 & 9.75 & - & - \\
\hline $1981-1985$ & 70710.20 & 256.94 & 28175.20 & 256.94 & 2535.00 & 0.00 & - & - \\
\hline $1986-1990$ & 71703.20 & 290.88 & 29168.20 & 290.88 & 2535.00 & 0.00 & - & -. \\
\hline 1991-1995 & 72580.20 & 194.97 & 30060.40 & 220.59 & 2535.60 & 1.34 & 16004.90 & 647.79 \\
\hline $1996-2000$ & 71297.00 & 809.20 & 29380.00 & 867.18 & 2572.80 & 50.83 & 13956.40 & 647.79 \\
\hline 2001-2005 & 74120.00 & 1649.85 & 32400.00 & 1816.59 & 2880.00 & 130.38 & 11908.20 & 647.63 \\
\hline 2006-2009 & 77000.00 & 1683.25 & 36375.00 & 1600.78 & 3000.00 & 0.00 & 10065.00 & 528.79 \\
\hline All & 71501.80 & 2321.91 & 29299.98 & 2788.79 & 2582.59 & 181.58 & 13342.08 & 2423.54 \\
\hline F-value & \multicolumn{2}{|c|}{$43.92^{\star \star \star}$} & \multicolumn{2}{|c|}{$60.12^{\star \star \star}$} & \multicolumn{2}{|c|}{$79.59^{* \star \star}$} & \multicolumn{2}{|c|}{$67.50^{\star \star \star}$} \\
\hline
\end{tabular}

Source: FAOSTAT database 2012

Table 3. Productivity grades of Nigerian soils.

\begin{tabular}{llcr}
\hline \multirow{2}{*}{ Soil productivity grade } & \multirow{2}{*}{ FAO productive classes } & \multicolumn{2}{c}{ Land area } \\
\cline { 3 - 3 } & & $\left.\mathbf{( K M}^{\mathbf{2}}\right)$ & \% of total \\
\hline High (1) & None & - & 5.52 \\
Good (2) & Fluvisols, Gleysols, Regosols & 50.4 & 46.45 \\
Medium (3) & Lixisols, Cambisols, Luvisolsand Nitisols & 423.6 & 31.72 \\
Low (4) & Arisols, ferralsols, Alisols, and Vertisols & 289.2 & 16.31 \\
Very low (5) & Arenosols and Nitosols & 148.8 & \\
\hline
\end{tabular}

Source: Agboola (1979).

to 1995 , after which it decreased to $71,297,000$ ha in the 1996 to 2000 period. However, from its average value in 1996 to 2000 , it drastically increased to $77,000,000$ ha in 2006 to 2009. Between 1961 and 2009, average agricultural land area cultivated is $71,501,800$ ha with standard deviation of $2,321,910$. F test shows that there is statistical significance $(p<0.001)$ in the means of agricultural land areas across the periods.

Table 2 further shows that the average arable land area in Nigeria increased from 26,600,000 ha in 1961 to 1965 to $30,060,400$ ha in 1991 to 1995 . However, the value decreased to $29,380,000$ ha in 1996 to 2000 before increasing to $36,375,000$ in 2006 to 2009 . Average arable land in 1961 to 2009 is $29,299,980$ ha with standard deviation of $2,788,790$. F test shows that there is statistical significance $(p<0.001)$ in the means of arable land areas across the periods. The areas of land under forests in Nigeria have declined since the 1960s. Table 3 shows that out of all the land use classifications, it is only forest and woodland that shows steady decline during the years studied. This implies that despite the different programs of the State and Federal Governments on reforestation, the rates of clearing mature forests still exceed the rates of replanting those ones already cleared. The mean forestland area between 1991 and 2009 is 13342,080 ha with standard deviation of $2,423,540$. F test shows that there is statistical significance $(p<0.001)$ in the means of forest land areas across the periods.

The table also reveals that the land areas of permanent crops increased steadily from 2,404,000 ha in 1961 to 1965 to $3,000,000$ ha in 2006 to 2009 period. Between 1961 and 2009, land areas devoted to permanent crops has an average value of 2,582,590 ha with standard deviation of 181,580 . $F$ test shows that there is statistical significance $(p<0.001)$ in the means of permanent cropland areas across the periods.

\section{LAND DEGRADATION AND THE NIGERIAN AGRICULTURE}

Land use in many African nations has been characterized by a significant amount of land degradation. Moreover, these two processes are clearly related (Barbier, 1999). Many poor African pastoralists and farming households 
respond to declining land productivity by abandoning existing degraded pasture and cropland, and moving to new lands for grazing and crop cultivation.

Land degradation has been defined in different ways by different authors based on differences in their focal points. For instance, Blakie and Brookfield (1987) defined land degradation as a process of reducing the value of land. ADB (1995) also submitted that land degradation is a reduction in the productivity of land resulting from soil loss, breakdown in soil structure, water logging, nutrient loss, and pollution from toxic substances. It can be viewed as any act on land that changes it from its natural ecological state and makes it unfit for effective use. Land degradation is the reduction in the capacity of the land to produce benefits from a particular land use under a specified form of land management (Blakie and Brookfield, 1987). If soil is degraded, its productivity is reduced and may be further reduced until steps are taken to stop further degradation and restore its productivity. The unhindered degradation of soil can completely ruin its productive capacity for human uses (Douglas, 1994).

Rapid population growth and intensification of land use are part of the reasons for increasing soil degradation. Also, a high percentage of tropical soils is unstable and have low inherent fertility. It had thus been estimated that about $64 \%$ of agricultural land in Africa is low potential land (FAO, 1984). One of the major factors leading to non-sustainability of agriculture in the sloping uplands is soil erosion (Blackie and Brockfield, 1987). Although the extent of anthropomorphic soil erosion is debatable (Oldeman et al., 1991), activities like deforestation and intensive land use in the upland have undoubtedly led to increased soil erosion (Oyekale and Adepoju, 2012).

FAO (1991) highlighted some possible causes of land degradation. These could be reduced fallow period of agricultural land, steep slope cultivation, intensive land cultivation, and depletion of organic matter during cultivation. Conventionally, however, soil erosion has been perceived as the major cause of land degradation (Shaxson et al., 1997; FAO, 1991). Biswas (1979) stressed that soil loss is one of the most pressing and difficult problems facing the future of mankind. It should also be noted that rapid population growth in tropical and sub-tropical countries and persistent intensification of crop production are other major causes of land degradation (FAO, 1984). In Nigeria, land degradation is now very serious because of the rapidly increasing human and animal population. This has resulted into extension of crop cultivation to marginal land, reduction of fallow period, and to a greater extent, continuous cropping (FAO, 1991).

The extent of land degradation in Nigeria is presently alarming, and no part of the country is entirely excluded. However, compared with some other African countries, Nigeria is blessed with abundant land and water resources, which are capable of indefinite regeneration over a given period of time if the prevailing management practices are conducive. The management issue cannot be taken for granted, given that these resources constitute the productive base for the Nigerian agriculture, upon which the livelihoods of many rural and urban households depend. It should also be emphasized that the agricultural sector is the mainstay of the Nigerian economy with significant contributions to the Gross Domestic Product (GDP) (Oyekale, 2012). However, land degradation is seriously undermining the performance of the Nigerian agricultural sector. Udoh (2006) also noted that the performance potential of the sector is still very much under-utilized because the greater proportions of the farmers are practicing low external input agriculture (LEIA). Due to increasing demographic and environmental pressures and some pertinent changes in the social and political situations, these traditional farming systems are suffering from several internal and external disruptions. Precisely, some cases of considerable degradation of the natural resource base have been reported, particularly with increasing agricultural intensefication. Similarly, under the LEIA, the choice of land use, allocation and management may not necessarily reflect proper and adequate practices. This problem is further compounded by constraints such as financial status of the farmers, information asymmetry in relation to soil properties, suitability and capabilities, among others (Oyekale and Idjesa, 2009).

It should be further emphasized that poor incentives for natural resource conservation, among other socioeconomic constraints, have subjected the fragile soil nutrients to serious exploitation and depletion. Nigerian policy makers have now come to understand that sustainable management of land is a prerequisite for providing enabling environment for agricultural development, which is pivotal for ensuring that food, which is the basic need of man is adequately available, accessible and affordable for the rapidly growing populations. This goal, which is directly related to achieving the Millennium Development Goal (MDG) of reducing poverty level by 2015 , calls for conscientious and concerted efforts that are set towards monitoring and evaluating the extent of progress in land management, with timely responses to early warnings and critical alerts.

Land monitoring and evaluation assess the trends in the performance and suitability of land for some specified uses. In order to achieve high and sustained production as well as preserve ecological stability, some factors must be borne in mind when the land is being cleared for agricultural production. These are preservation of the delicate ecological balance among vegetation, climate and soil; maintenance of a regular and adequate supply of organic matter on the soil surface; encouragement of soil faunal activity; maintenance of physical condition of the soil suited to land use; replenishment of soil nutrients that are removed by cropping; creation of a desirable nutrient balance and soil reaction; prevention of a build up of pests and undesirable plants; adaptation of a 
natural nutrient recycling mechanism to avoid leaching losses of nutrients; and preservation of ecological diversity.

In Nigeria, the issues of concern to sustainable agriculture include the problems of soil vis-à-vis human induced soil degradation, bush burning and soil compaction (FAO, 2000). The problem of resource degradation has been identified as the most crucial environmental challenge that faces the nation (World Bank, 1990). This conclusion was reached based on its great economic significance, the wide area of land that is affected, and the large number of people whose economic activities are directly hampered. Specifically, the problem of land degradation affects about 50 million Nigerians, and an estimated annual cost of US $\$ 3$ billion is to be borne by the Federal Government. However, this conservative estimate only reflects the cost of food replacement through importation without considering the costs of health hazards that could likely result (World Bank, 1990). Similarly, natural resource degradation and accelerated rates of population growth have significantly undermined the productive capacity of majority of the Nigerian soils (FAO, 1991; Higgins and Antoine, 1991).

Deforestation accelerates the speed of land degradation, and affects the socio-economic activities and the natural ecosystem of most tropical countries. Developing countries' economic planners are now faced with a dilemma because although forest resources must be cut to increase food production in the short-term period, depletion of these resources can lead to reduction of agricultural production in the long run (Ehui et al., 1990). This is as a result of high correlation that exists between the fertility level of tropical soils and the intensity of biomass coverage mostly in form of forests. Forests also help in accelerating the process of soil formation, formation and maintenance of good soil structure, and prevention of excessive soil erosion (IBRD, 1978; OTA, 1984; Sanchez, 1976, 1981).

FDALR (1982) noted that over $90 \%$ of the total land area in Nigeria suffers from one form of erosion or another, with sheet erosion occurring throughout the country. Therefore, degraded agricultural land will further lead to reduction in farm output, Gross National Product (GNP), and environmental quality. The negative impact these could have on agricultural production would lead to increased food prices, increased rate of inflation, widespread malnutrition, famine, and general reduction in people's standard of living. Resource degradation therefore puts further strains on the prospects of fighting hunger in many developing nations (Erenstein, 1999).

Moreover, the problem of sustaining growth in agricultural production emanates from unplanned land use and inability to give adequate attention to physical, biological and ecological implications of agricultural intensification (Barbier, 2001). Consequently, crop yields on some of the high potential and high input areas of the tropics have now started to decrease, while the reserves of unused lands are decreasing and the resource base of agriculture continues to be degraded (FAO, 1997).

Land can be productive or non-productive for agricultural purposes. A qualitative appraisal of the productivity rating of Nigerian soils is in Table 3 , and it reveals that none belongs to the highly productive class 1 ; only $5.52 \%$ belongs to class 2 , while the highest proportion of $31.72 \%$ belongs to the low productive class 4. Given the dynamics of land use, this classification would have been worse than what was got in 1979. However, the scope of the problem can be well conceptualized from the fact that, despite that Nigeria becomes highly dependent on oil revenue since the 1970s, land remains the most important long term resource base for the direct and indirect support of plants and animals, which man uses (NEST, 1991).

Given the level of agricultural technology development in Nigeria, there are 40 to 50 million people in excess of the land's supporting capacity at present who are just mining the soil to support themselves (FAO, 2000). In addition, widespread poverty and income inequality also confront the households' decisions for any investment in soil conservation practices (Barbier, 2001). Without being addressed, such economic condition is liable of culminating into serious ecological crises (WCED, 1987). Sustainable development would therefore be compromised under impoverished situation where shortterm survival takes precedence over long-term productivity. In some northern states, for instance, just as it is happening in some nations in North Africa, ecology degrading activities by the private and public sectors are in urgent need of remediation. Many irrigation projects have ended up displacing poor farmers and pastoralists from their traditional sources of water and land. Thus, they are forced to move to more fragile lands that are prone to erosion (Barbier and Thompson, 1998; Barbier, 2000).

Conventional wisdom therefore teaches that a central and crucial point in the performance of Nigerian agriculture in the last three decades is the issue of production sustainability. This can be vividly seen from the persistent stagnation in agricultural production resulting from low resource productivity of small-scale farmers that dominate the food production sub-sector. Figure 1 shows the distribution of average per capita agricultural production indices in Nigeria during the 1961 to 2010 period. It reveals that average per capita production indices were generally higher in total agriculture, cereals, crops, food and livestock during the 1991 to 2010 period. However, in non-food, average production index during 1961 to 1970 was higher than other years. Figure 2 also reveals the trend of the production indices. It shows that livestock production indices steadily increased in the past two decades, while non-food decline sharply since 2006. In fact, except in livestock, production indices in almost all agricultural categories fluctuated and declined after 2006. 


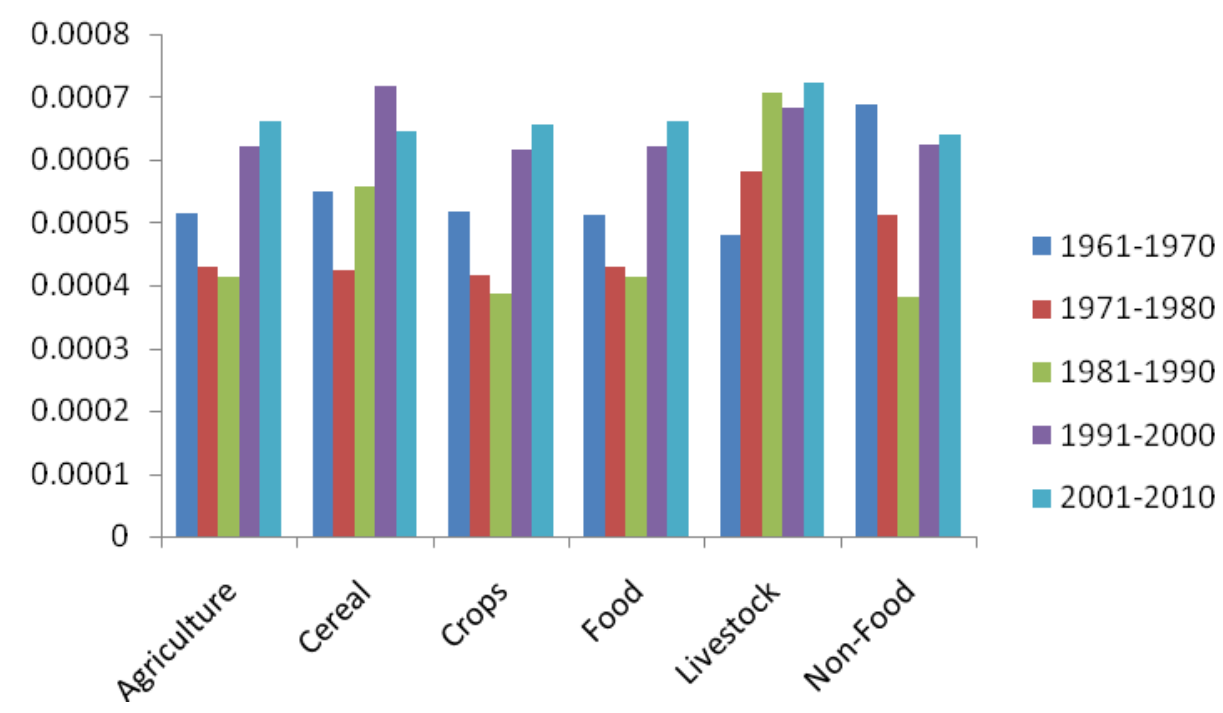

Figure 1. Distribution of Per Capita Agricultural Production Indices in Nigeria (1961-2010) Source: FAOSTAT database 2012.

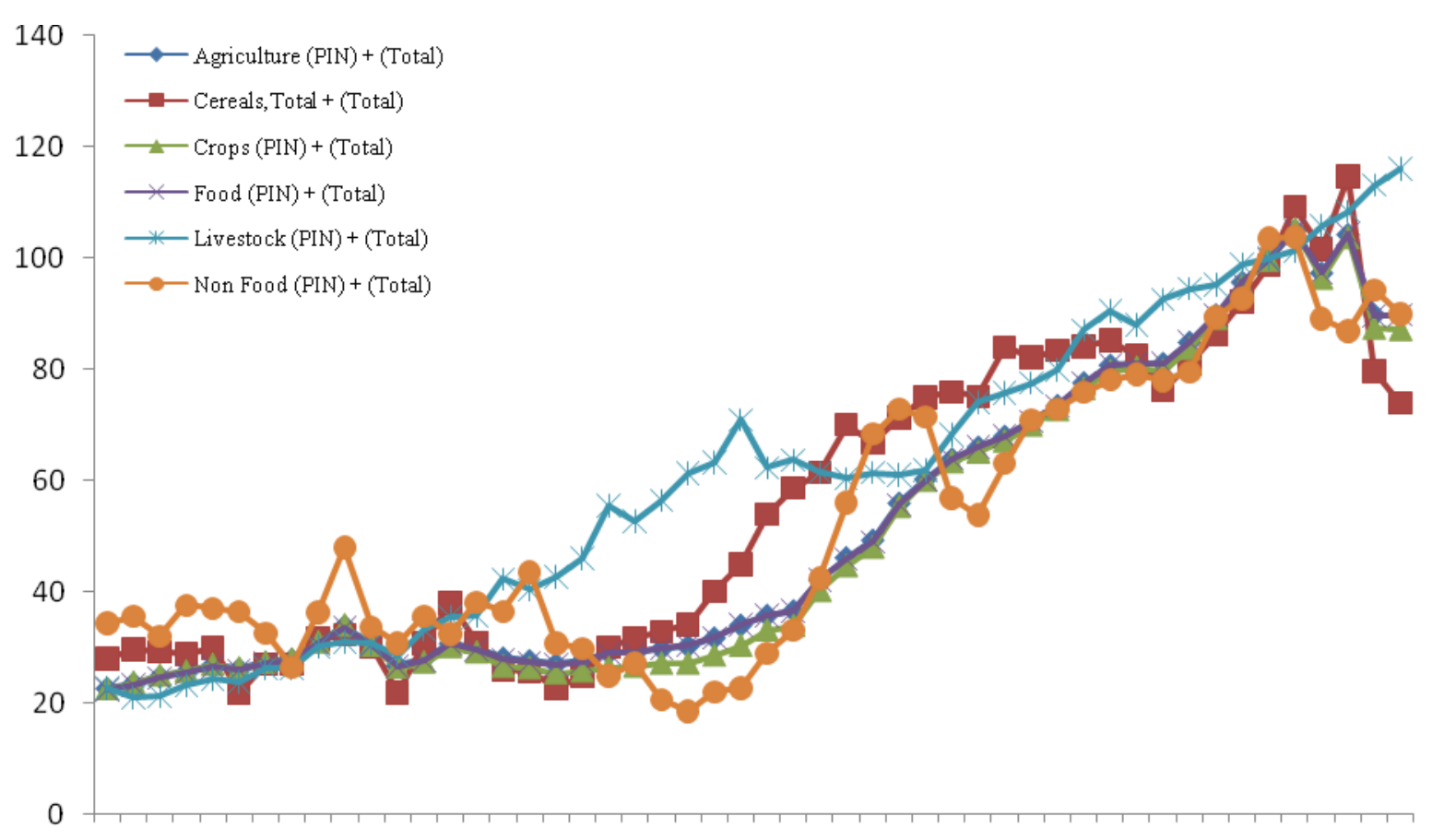

12345678991011121314151617181920212223242526272829303132333435363738394041424344454647484950

Figure 2. Trends ofAgricultural Production Indices in Nigeria (1961-2010) Source: FAOSTAT database 2012.

Table 4 shows the distribution of average land areas cultivated to some major crops and their percentage changes. It reveals that rice, potato, sweet potato, cassava, soybean, coconut, tomato, okra and vegetables cultivate showed increasing trend in land areas harvested. This implies that land areas grown to these crops have steadily increased over the years. However, potato shows sporadic increase with $670.67 \%$ and
$359.44 \%$ between period $2(1981 / 1990)$ and 3 $(1991 / 2000)$ and $3(1991 / 2000)$ and 4 (2001/2010), respectively. It can be concluded that only in very few crops have average land areas harvested recently declined.

Table 5 presents the quantities of average seed planted per hectare during the period 1961 to 2010. It reveals that average seeds planted recently declined in 
Table 4. Percentage Changes in Average Land Areas Harvested in Some Nigerian Crops (1961-2010) (Ha).

\begin{tabular}{|c|c|c|c|c|c|c|c|c|c|}
\hline \multirow[b]{2}{*}{ Crop } & \multicolumn{5}{|c|}{ Average } & \multicolumn{4}{|c|}{ Percentage change } \\
\hline & $\begin{array}{c}1961-1970 \\
\text { (1) }\end{array}$ & $\begin{array}{c}1971-1980 \\
(2)\end{array}$ & $\begin{array}{c}1981-1990 \\
\text { (3) }\end{array}$ & $\begin{array}{c}1991-2000 \\
(4)\end{array}$ & $\begin{array}{l}2001-2010 \\
\text { (5) }\end{array}$ & $1 \& 2$ & $2 \& 3$ & $3 \& 4$ & $4 \& 5$ \\
\hline Wheat & 10400 & 10650 & 39400 & 32820 & 47420 & 2.40 & 269.95 & -16.70 & 44.49 \\
\hline Rice, paddy & 206600 & 310400 & 849600 & 1865620 & 2248840 & 50.24 & 173.71 & 119.59 & 20.54 \\
\hline Maize & 1273300 & 804000 & 2277200 & 4551140 & 3546772 & -36.86 & 183.23 & 99.86 & -22.07 \\
\hline Millet & 4437400 & 3822700 & 2981200 & 5174700 & 4501520 & -13.85 & -22.01 & 73.58 & -13.01 \\
\hline Sorghum & 5417300 & 3949100 & 4011120 & 6142800 & 6674646 & -27.10 & 1.57 & 53.14 & 8.66 \\
\hline Potatoes & 2002.3 & 3990 & 6990 & 53870 & 247500 & 99.27 & 75.19 & 670.67 & 359.44 \\
\hline Sweet potatoes & 13900 & 11500 & 15700 & 307520 & 968729.2 & -17.27 & 36.52 & 1858.73 & 215.01 \\
\hline Cassava & 867800 & 1051000 & 1288791 & 2941290 & 3530385 & 21.11 & 22.63 & 128.22 & 20.03 \\
\hline Taro (cocoyam) & 268800 & 140000 & 95700 & 325301 & 628022.1 & -47.92 & -31.64 & 239.92 & 93.06 \\
\hline Yams & 761100 & 726900 & 923300 & 2166389 & 2884803 & -4.49 & 27.02 & 134.64 & 33.16 \\
\hline Cow peas, dry & 2881200 & 2402800 & 1427800 & 3448774 & 3737058 & -16.60 & -40.58 & 141.54 & 8.36 \\
\hline Kolanuts & 161000 & 134000 & 153500 & 102160.3 & 137703.3 & -16.77 & 14.55 & -33.45 & 34.79 \\
\hline Soybeans & 178700 & 220000 & 371000 & 535850 & 555186 & 23.11 & 68.64 & 44.43 & 3.61 \\
\hline Groundnuts, with shell & 1936400 & 1236100 & 659500 & 1761720 & 2191358 & -36.17 & -46.65 & 167.13 & 24.39 \\
\hline Coconuts & 30500 & 32900 & 35200 & 36350.8 & 38720 & 7.87 & 6.99 & 3.27 & 6.52 \\
\hline Oil palm fruit & 2425000 & 2125000 & 2163000 & 2831800 & 3215500 & -12.37 & 1.79 & 30.92 & 13.55 \\
\hline Tomatoes & 19810 & 26600 & 35250 & 74941.1 & 164760.5 & 34.28 & 32.52 & 112.60 & 119.85 \\
\hline Chillies and peppers, green & 54150 & 64000 & 80004.8 & 83835.1 & 83250.6 & 18.19 & 25.01 & 4.79 & -0.70 \\
\hline Onions (inc. shallots), green & 10000 & 10000 & 10047.6 & 16868.4 & 12501.7 & 0.00 & 0.48 & 67.88 & -25.89 \\
\hline Onions, dry & 25000 & 30000 & 32666.7 & 45955.1 & 41206.5 & 20.00 & 8.89 & 40.68 & -10.33 \\
\hline Carrots and turnips & 20000 & 20000 & 20300 & 25253.1 & 26385.6 & 0.00 & 1.50 & 24.40 & 4.48 \\
\hline Okra & 153500 & 176500 & 231400 & 338886.2 & 350118.5 & 14.98 & 31.10 & 46.45 & 3.31 \\
\hline Maize, green & 127300 & 80400 & 121800 & 268767.9 & 180194.6 & -36.84 & 51.49 & 120.66 & -32.96 \\
\hline Vegetables fresh nes & 194988 & 237500 & 256500 & 520217.3 & 675400.4 & 21.80 & 8.00 & 102.81 & 29.83 \\
\hline Plantains & 198000 & 180000 & 170570 & 264700 & 451268 & -9.09 & -5.24 & 55.19 & 70.48 \\
\hline Cocoa beans & 700000 & 700000 & 702300 & 766150 & 1166022 & 0.00 & 0.33 & 9.09 & 52.19 \\
\hline Cereals, Total + (Total) & 11413200 & 8923350 & 10202020 & 17875350 & 17170667 & -21.82 & 14.33 & 75.21 & -3.94 \\
\hline Roots and Tubers, Total + (Total) & 1913602 & 1933390 & 2330481 & 5794370 & 8259439 & 1.03 & 20.54 & 148.63 & 42.54 \\
\hline
\end{tabular}

Source: FAOSTAT database 2012.

all the crops except groundnut with shell. This either reveals availability of better seeds with higher percentage germination or inability to ensure adequate spacing of crops due to presence of marginal lands within the cultivate plots. Table 6 shows the average yield per hectare in some major Nigerian crops. It reveals that although there were significant fluctuations in crop yields since 1961, average yields in cereals, vegetables, 
Table 5. Average Seeds Planted Per Hectare in Some Nigerian Crops (1961-2010) (kg).

\begin{tabular}{lccccc}
\hline Crop & $\mathbf{1 9 6 1 - 1 9 7 0}$ & $\mathbf{1 9 7 1 - 1 9 8 0}$ & $\mathbf{1 9 8 1 - 1 9 9 0}$ & $\mathbf{1 9 9 1 - 2 0 0 0}$ & $\mathbf{2 0 0 1 - 2 0 1 0}$ \\
\hline Wheat & 51.20 & 49.30 & 55.08 & 50.30 & 48.44 \\
Rice, paddy & 53.75 & 54.77 & 56.19 & 51.25 & 49.27 \\
Maize & 24.69 & 22.57 & 30.16 & 23.98 & 25.04 \\
Millet & 16.15 & 14.71 & 17.53 & 15.91 & 15.82 \\
Sorghum & 20.27 & 18.32 & 21.73 & 20.29 & 19.49 \\
Potatoes & 871.23 & 916.04 & 896.21 & 1169.68 & 863.05 \\
Cow peas, dry & 38.13 & 31.19 & 36.75 & 36.76 & 33.97 \\
Soybeans & 28.58 & 29.27 & 29.27 & 28.27 & 26.80 \\
Groundnuts, with shell & 71.11 & 63.52 & 75.06 & 72.40 & 72.89 \\
\hline
\end{tabular}

Source: FAOSTAT database 2012.

Table 6. Average Yield per Hectare in Some Major Agricultural Crops in Nigeria (1961-2010).

\begin{tabular}{lccccc}
\hline Crop & $\mathbf{1 9 6 1 - 1 9 7 0}$ & $\mathbf{1 9 7 1 - 1 9 8 0}$ & $\mathbf{1 9 8 1 - 1 9 9 0}$ & $\mathbf{1 9 9 1 - 2 0 0 0}$ & $\mathbf{2 0 0 1 - 2 0 1 0}$ \\
\hline Wheat & 18060.61 & 18443.20 & 17983.23 & 19487.85 & 12442.35 \\
Rice, paddy & 12553.13 & 16897.23 & 20798.29 & 16856.65 & 15140.51 \\
Maize & 8907.78 & 10546.32 & 13091.13 & 12768.43 & 17519.83 \\
Millet & 5904.33 & 7987.93 & 13233.29 & 10234.42 & 14371.61 \\
Sorghum & 7305.40 & 8418.42 & 12105.77 & 10986.68 & 11691.58 \\
Potatoes & 109553.90 & 79707.67 & 63158.68 & 55147.62 & 31563.34 \\
Sweet potatoes & 117311.10 & 87954.54 & 67362.09 & 44660.10 & 29818.87 \\
Cassava & 96806.49 & 100669.20 & 104006.40 & 105232.50 & 110671.10 \\
Taro (cocoyam) & 56290.56 & 39379.95 & 39314.58 & 57168.21 & 68913.90 \\
Yams & 87001.05 & 98843.09 & 71188.09 & 106181.60 & 107536.80 \\
Cow peas, dry & 2394.17 & 2872.78 & 5232.58 & 5283.37 & 7051.93 \\
Kolanuts & 9429.85 & 9553.99 & 10073.96 & 10603.19 & 8418.37 \\
Soybeans & 3453.45 & 3106.14 & 2904.43 & 5347.94 & 9639.00 \\
Groundnuts, with shell & 9365.57 & 7536.66 & 11239.77 & 11548.83 & 14108.75 \\
Coconuts & 28187.11 & 28392.82 & 30061.75 & 41198.83 & 50654.13 \\
Oil palm fruit & 25000.00 & 25000.00 & 25962.18 & 26511.43 & 26485.82 \\
Tomatoes & 99478.47 & 98294.85 & 100000.00 & 88967.77 & 71967.24 \\
Chillies and peppers, green & 80189.19 & 86785.10 & 89525.32 & 79240.99 & 83219.34 \\
Onions (inc. shallots), green & 78800.00 & 84500.00 & 106932.00 & 133719.90 & 190346.80 \\
Onions, dry & 140000.00 & 133333.30 & 137574.50 & 140444.30 & 155994.40 \\
Carrots and turnips & 75000.00 & 75000.00 & 75768.40 & 80148.00 & 91521.69 \\
Okra & 17092.93 & 20211.89 & 21874.98 & 19779.73 & 26429.49 \\
Maize, green & 22296.46 & 27221.52 & 30027.29 & 27347.50 & 37067.67 \\
Vegetables (fresh) & 47777.60 & 46793.73 & 48343.76 & 59163.49 & 74501.65 \\
Plantains & 45002.22 & 56622.22 & 65614.06 & 65478.96 & 56414.03 \\
Cocoa beans & 3296.43 & 2825.28 & 2619.70 & 3890.66 & 3393.48 \\
Cereals (Rice Milled Eqv) & 6923.58 & 8480.74 & 12786.29 & 11188.75 & 13381.66 \\
\hline Sour FAOSTAT & & & & &
\end{tabular}

Source: FAOSTAT database 2012

maize, okra, carrot, onion, chilly, coconut, groundnut, soybean, cowpea, yam, cocoyam, cassava, sorghum, millet and maize have recently increased. This implies that with technological innovation diffusion and adoption of improved seeds, average crop yields had increased over the years.
However, Figure 3 shows that the trends of yields in all the cereal crops declined between 2009 and 2010. This shows that recent cereal production activities are not sustainable given the fact that land areas harvested increased but yields are on the downward trend. Similar finding is presented in Figure 4 where yields many root 


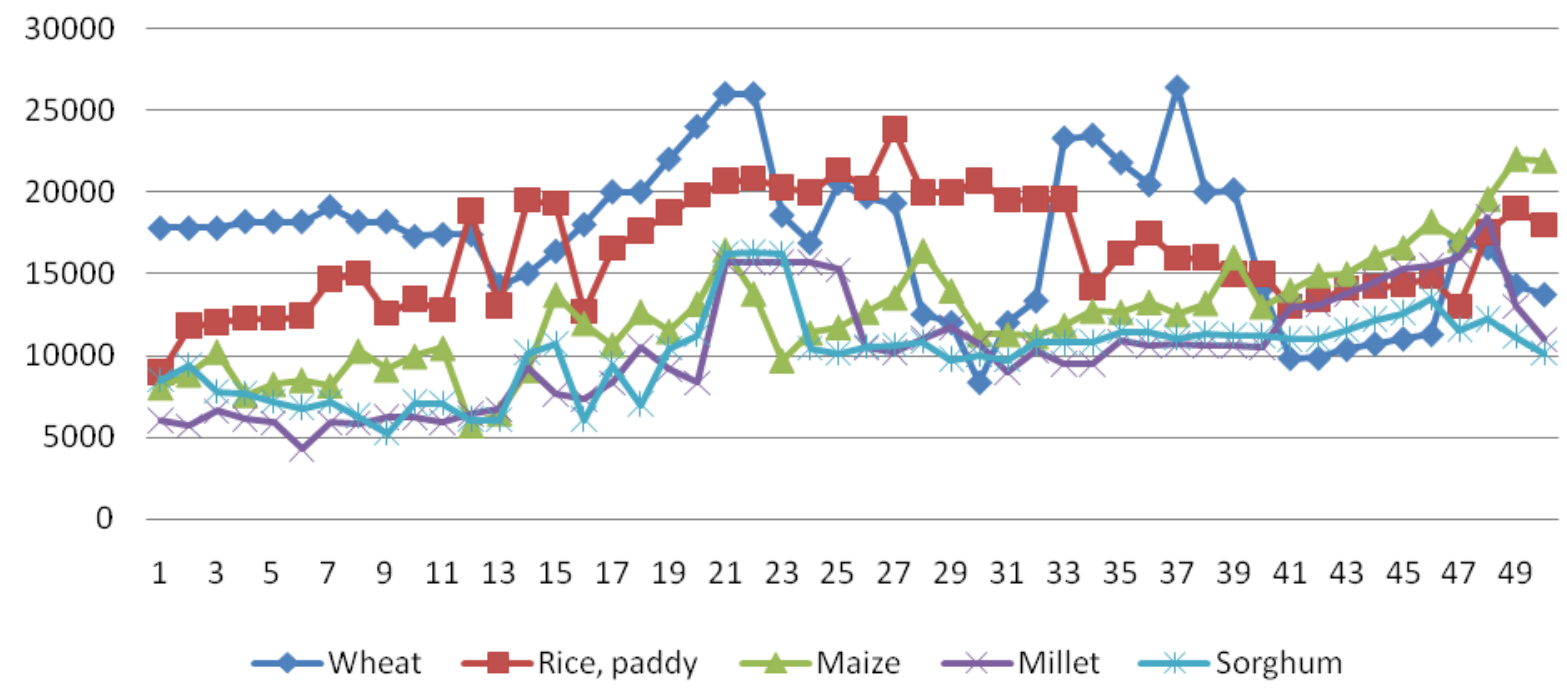

Figure 3. Trends of yield per hectare in selected cereal crops in Nigeria (1961-2010). Source: FAOSTAT database 2012.

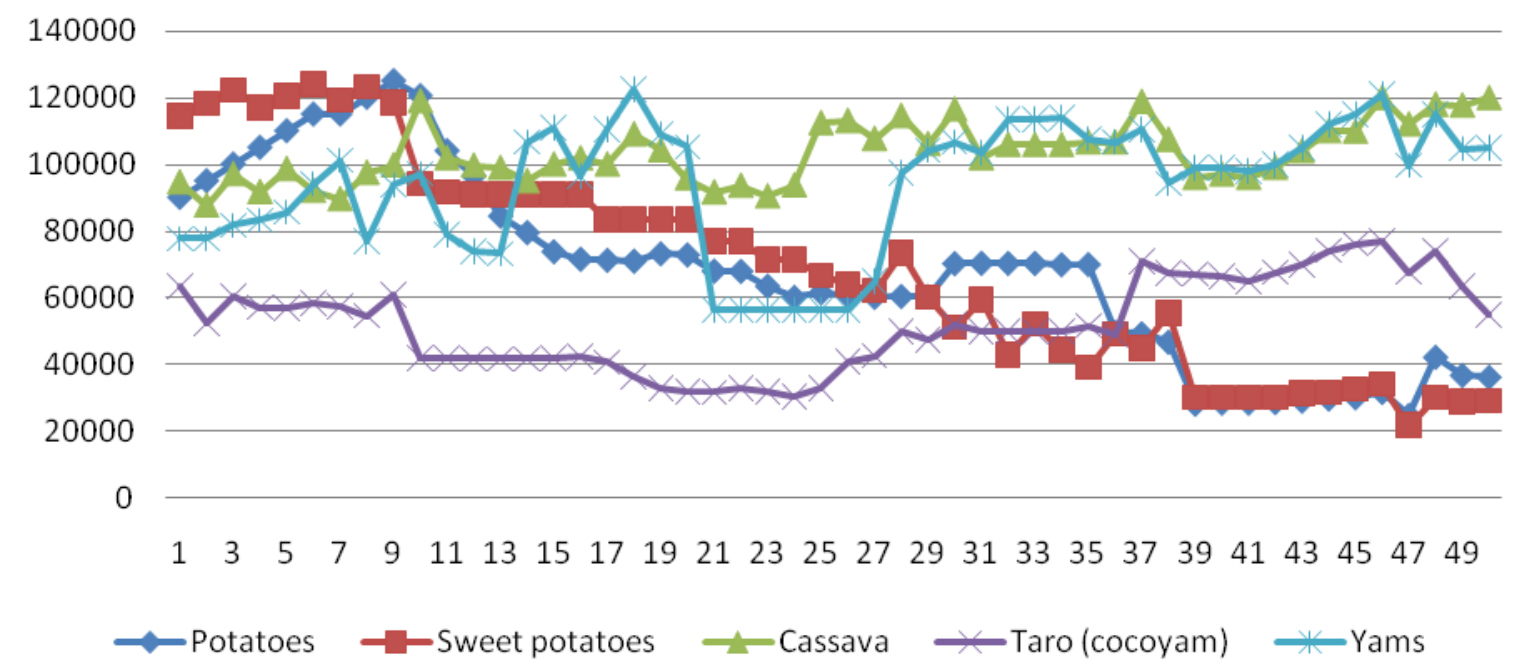

Figure 4. Trends of yield per hectare in selected tuber and root crops in Nigeria (1961-2010). Source: FAOSTAT database 2012.

and tuber crops declined between 2008 and 2010. Many factors could have been responsible such as climatic change in some Nigerian states, land infertility, land of adequate inputs of fertilizers, among others.

\section{CONCLUSION}

The dynamics of land use in many African nations have resulted into land degradation largely accelerated by progressive deforestation. Recently, the existence of synergistic, intricately interwoven and mutually reinforcing nexus between agriculture, population and the environment in many nations of the Sub-Saharan Africa (SSA) has been recognized (Cleaver and Schreiber,
1993, 1994). Considerable interest in research dealing with empirical analysis of the relationship between agriculture and some identified indicators of the environment has therefore developed on a global basis. Therefore, land degradation and persistent decline in agricultural productivity in Nigeria call for urgent policy attentions. The trends of land use have shown relatively high degree of dependence on forestland for agricultural expansion and other industrial/urban uses. The trends of forestlands are therefore on the downward side, though government had put in place some afforestation projects. Also, areas harvested of many crops had rapidly increased since 1960s. Average crop yields have also recently increased, showing some positive benefits from technological innovations. It is therefore important for the 
government to ensure adequate land use planning in conjunction with all stakeholders in the agricultural sector. Such plans should critically evaluate nation's needs of land in the nearest future and how current uses can ensure sustainability in the long term period. Promotion of research into development of hybrids crops with more resistance to environmental stress also promises to offer some hope of increased crop yields as human population grows and puts more pressure on the land resources.

\section{REFERENCES}

ADB (1995). Country Environmental Profile: Sierra Leone.Environmental and Social Policy Working. pp. 17-50.

Adegeye AJ, Dittoh J (1985). Essentials of Agricultural Economics.lbadan: Impact Publishers Nigeria Limited.

Adegboye RO (1986). Land tenure and land use pattern. A Final Report on Oyo State Feasibility Study of Statewide Agricultural Development Project.Federal Military Government of Nigeria/ FACU.

Adegboye RO (1966). Analysis of Land Tenure Structure in Some Parts of Nigeria.Nigeiran J. Econ. Soc. Stud. 8:259-268.

Agboola SA (1979). An Agricultural Atlas of Nigeria, Oxford Nigeria, Oxford University Press, Oxford. $248 \mathrm{pp}$.

Akinbola GE (1993). Changes in Land Use Patterns, Soil Characteristics and Potentials for Agriculture in Ibadan Urban Area.Ph.D. Thesis, University of Ibadan, Ibadan.

Allen JC, Barnes DF (1985). The Causes of Deforestation in Developing Countries. Ann. Assoc. Am. Geogr. 75(2):163-84.

Barbier EB (2000). The Economic Linkages Between Rural Poverty and Land Degradation: Some Evidence from Africa. Agric. Ecosyst. Environ. 82:355-370

Barbier EB (1999).The Economics of Land Degradation and Rural Poverty Linkage in Africa. In: Proceedings of the UNV/INRA Annual Lectures on Natural Resource Conservation and Management in Africa. Tokyo: United Nations University Press. 132 pp.

Barbier EB (2001).The Economics of Tropical Deforestation and Land Use: An Introduction to the Special Issue. Land Econ. 77(2):155-171.

Barbier EB, Burgess JC (1997).The Economic of Tropical Forest Land Use Change Land Econ. 73(2):174-195.

Barbier EB, Thompson JR (1998). The Value of Water, Floodplain Versus Large Scale Irrigation Benefits in Northern Nigeria. Ambio 27(6):434-440.

Biswas AK (1979). Agricultural Development and the Environment. Mazingira 11:7-13.

Blackie P, Brookfield H (1987).Land Degradation and Society. London and New York: Methuen.

Cleaver KM, Schreiber GA (1993). The Population Environment and Agriculture Nexus in Sub-Saharan Africa, In: Srivastava JP, Alderman $\mathrm{H}$ (Eds.) Agriculture and Environmental Challenges Proceedings of the Thirteenth Agricultural Sector Symposium. Washington, D.C.: IBRD/World Bank. pp. 199-214.

Cleaver KM, Schreiber GA (1994). Reversing the Spiral. The Population, Agriculture and Environment Nexus in Sub-Saharan Africa. Washington D.C.: The World Bank. 293 pp.

Douglas M (1994).Sustainable Use of Agricultural Soils. A Review of he Prerequisites for Success or Failure. Development and Environmental Report No. 11.Group for Development and Environment, Institute of Geography, Beine University, Switzer land.

Erenstein OCA (1999). The Economics of Soil Conservation in Developing Countries: The Case of Crop Residue Mulching. Wageningen University.

Falusi AO (1997). Agricultural Development and Food Production in Nigeria: Problem and Prospects". In: Shaib, B. N.O.Adedipe, A. Aliyu, and M.M. Jir (eds.) Integrated Agricultural Production in Nigeria: Strategies and Mechanisms for Food Security. Monograph No.5. Abuja: National Agricultural Research Project.

FAO (1984). Land, Food and People. Economic and Social Development Series No. 30, FAO, Rome.
FAO (1991). Nigeria Land Resource Management Study. Vol. 1 Main Report and Annex 1. Rome: FAO.

FAO (1997). Technical Background Document for the World Food Summit Rome: FAO.

FAO (1997a). Forest Resources Assessment 1009: Survey of Tropical Forest Cover and Study of Change Processes. FAO Forestry Paper No. 130. Rome: FAO. 154 pp.

FAO (1998).Rural Women and Food Security: Current Situation and Perspectives. Rome.

FAO (2000). Land and Water Constraints to Sustainable Agriculture www.fao.org/waicent/faoinfo/agricult/agl/swlwpur/nigeria/e bright.htm

FAOSTAT (2012). FAO Database. Internet file retrieved from FAOSTAT www.fao.org

FDALR (1982). The Need for Land Resource Services to the States, In: FDALR (ed) Efficient Use of Nigerian Land Resources. Federal Department of Agricultural Land Resources.

Higgins GM, Antoine J (1991). Nigeria Resource, Potential, Population, and Soil Degradation. Rome: FAO.

Hui S (1997). Deforestation: Humankind and the global ecological crisis.Internet file retrieved from http://www.aquapulse.net/knowledge/deforestation.html>

IBRD (1978). Forestry Sector Policy Paper. Washington DC: World Bank.

National Bureau of Statistics (NBS) (2011). Contributions of Agricultural Sector to Economy.Internet file retrieved from www.nigerianstat.gov.ng

NEST (Nigeria Environmental Study Action /Team) (1991). Nigeria's Threatened Environment: A National Profile. Nigeria: NEST.

Nwosu AC (1991). Issues in African Rural Development, Arlington (USA): Winrock International Institute for Agric. Develop. pp. 196-217.

Office of Technical Assessment (OTA) (1984). Africa Tomorrow: Issues in Technology, Agriculture, and Foreign Aid: A Technical Memorandum. Washington DC: US Congress.

Oldeman L, Hakkeling R, Sombroek W (1991).World Map for the Status of Human Induced Soil Degradation: An Explanatory Note. International Soil Reference and Information Center, UNEP, Nairobi, Kenya.

Oyekale AS (2007). Determinants of Agricultural Land Expansion in Nigeria: An Application of Error Correction Modeling (ECM). J. Central Eur. Agric. 8:301-310.

Oyekale AS, Idjesa E (2009).Adoption of improved maize seeds and production efficiency in Rivers State, Nigeria. Acad. J. Plant Sci. 2(1):44-50.

Oyekale AS (2012).Intensive Land Use, Land Management and Efficiency of Food Production in the Niger Delta Region of Nig. Electr. J. Environ. Agric. Food Chem. 11(3):188-204.

Oyekale, AS, AdepojuAO (2012). Determinants of Agricultural Intensification in South-west Nig. Life Sci. J. 9(3):370-376.

Reardon MJ (1998). The Role of Tenure Security and Private Time Preference in Neotropical Deforestation. Land Econ. 74:162-170.

Saka JO, Okoruwa VO, Oni OA, Oyekale AS (2011). The Structure and Determinants of Land-use Intensity among Food Crop Farmers in Southwestern Nigeria. J. Agric. Sci. 3(1):194-205.

Sanchez P (1976). Properties and Management of Soil in the Tropics New York: John Wiley and Sons.

Sanchez P (1981). Soils of the Humid Tropics.Blowing in the Wind: Deforestation and Long range Implications.Studies in Third World Societies Pub.No. 14, Dept of Anthropology College of William and Mary.

Shaxson F,Tiffen M, Wood A, Turton C (1997). Better Land Husbandry: Rethinking Approach to Land Improvement and the Conservation of Water and Soil. Monographs, Natural Resource Perspective Overseas Development Institute, U.K.

Sheng TC (1989).Soil Conservation for Small Farmers in he Humid Tropics.FAO Soil Bulletin Volume 60. FAO: Rome.

Udoh EJ (2006). Modelling Indices of Efficiency and Sustainable Landuse and Management Among Migrant Farmers in a Farm Settlement of Cross River State, Nigeria. J. Agric. Soc. Sci. 2(2):67-71.

Vink APA (1975). Land Use, In:Advancing Agriculture Edited by Springer, V. and Berlin, H. Fidelberg New York.

Walker J (2002). Environmental indicators and sustainable agriculture. In: McVicar TR., Rui L, Walker J. Fitzpatrick RW. and Changming L 
6226 Afr. J. Agric. Res.

(eds), Regional Water and Soil Assessment for Managing Sustainable Agriculture in China and Australia, ACIAR Monograph No. 84, 323-332.

WCED (World Commission on Environment and Development) (1987). Our Common Future - The Brundtland Report. Oxford: Oxford

University Press. $247 \mathrm{pp}$.

World Bank (1990).Towards The Development of An Environmental Action Plan for Nigeria. Washington DC: The World Bank.

World Bank (1992).World Development Report1992. Washington DC: The World Bank.

World Bank (2001).World Development Indicators Database. Washington DC: The World Bank. 